\title{
Ubiquity of Euglena mutabilis Population in Three Ecologically Distinct Acidic Habitats in Southwestern Japan
}

\author{
Katsunori Yanagawa ${ }^{1}$, Akira Haraguchi ${ }^{1, *} \mathbb{1}$, Kai Yoshitake ${ }^{1}$, Katsuhiro Asamatsu ${ }^{1}$, Masanari Harano ${ }^{1}$, \\ Kei Yamashita ${ }^{2}$ and Jun-ichiro Ishibashi ${ }^{2}$ \\ 1 Faculty of Environmental Engineering, The University of Kitakyushu, Kitakyushu 808-0135, Japan; \\ kyanagawa@kitakyu-u.ac (K.Y.); y7551042@eng.kitakyu-u.ac.jp (K.Y.); a9mab001@eng.kitakyu-u.ac.jp (K.A.); \\ a9mab018@kitakyu-u.ac.jp (M.H.) \\ 2 Department of Earth and Planetary Sciences, Faculty of Science, Kyushu University, Fukuoka 819-0395, Japan; \\ keiy@kajima.com (K.Y.); ishibashi.junichiro.806@m.kyushu-u.ac.jp (J.-i.I.) \\ * Correspondence: akhgc@kitakyu-u.ac.jp
}

check for updates

Citation: Yanagawa, K.; Haraguchi, A.; Yoshitake, K.; Asamatsu, K.; Harano, M.; Yamashita, K.; Ishibashi, J.-i. Ubiquity of Euglena mutabilis Population in Three Ecologically Distinct Acidic Habitats in Southwestern Japan. Water 2021, 13, 1570. https://doi.org/10.3390/ w13111570

Academic Editor: Éva Ács

Received: 27 April 2021

Accepted: 31 May 2021

Published: 1 June 2021

Publisher's Note: MDPI stays neutral with regard to jurisdictional claims in published maps and institutional affiliations.

Copyright: (C) 2021 by the authors. Licensee MDPI, Basel, Switzerland. This article is an open access article distributed under the terms and conditions of the Creative Commons Attribution (CC BY) license (https:/ / creativecommons.org/licenses/by/ $4.0 /)$.

\begin{abstract}
Three strains of Euglena mutabilis were isolated from sediments in acidic inland water systems ( $\mathrm{pH}=3.4-4.7$ ), in Southwestern Japan-acid mine drainage in Sensui (Fukuoka), cold sulfidic spring in Bougatsuru (Oita), and a temporal pool in the Ebinokogen volcanic area (Miyazaki). All strains grew well in acidic media at $\mathrm{pH}$ 3.07. Phylogenetic analysis among these three strains showed high similarities to plastid SSU and nuclear SSU rRNA gene sequences $(99.86 \%$ and $99.76 \%$, respectively). They were closely related to the cultured isolates from other highly acidic habitats $(\mathrm{pH}=2.0-5.9)$. Concentration of sulfate, aluminum, calcium, and iron had 7-70 fold of differences among the three studied habitats. Our results imply that the rRNA genes of E. mutabilis have compensated for their low genetic diversity by adapting to a wide $\mathrm{pH}$ range, as well as various water chemistry of habitats.
\end{abstract}

Keywords: acid mine drainage; benthic Euglena; volcanic spring

\section{Introduction}

The flagellate Euglena mutabilis Schmitz is distributed in highly acidic inland water systems, such as coal or metal mine drainages [1,2], volcanic streams [3], and peat mire [4,5]. Mine drainage with biofilms of E. mutabilis is usually characterized by a low $\mathrm{pH}$ and high concentrations of heavy metals and sulfate. Nevertheless, E. mutabilis can tolerate extreme environmental conditions [6].

The lower $\mathrm{pH}$ limit of E. mutabilis habitats was reported to be 1.5 in coal mining sites in England [7], 1.5-2.2 in the Rio Tinto drains in Southern Spain [8], and 3.1 in a coal mining site in Indiana [2]. The upper $\mathrm{pH}$ limit of E. mutabilis habitats was reported to be 4.6-4.7 [2,6]. Bray et al. [9] reported that E. mutabilis could be found in circumneutral environments $(\mathrm{pH}=5.5-6.5)$ in the Southern Island of New Zealand, although its dominance within the algal community was low. Thus, the main habitats of E. mutabilis are acidic inland water systems with $\mathrm{pH}$ ranging from 1.5-4.7, and in algal communities under circumneutral environments.

The distribution of E. mutabilis populations is very limited, as highly acidic inland water systems show an isolated distribution. As mentioned above, the wide $\mathrm{pH}$ range of $E$. mutabilis habitats suggests that the species adapted from extremely acidic to circumneutral environments. The flagellate's population in each present habitat could have been genetically selected from the parent population with a high genetic diversity, and the selected population might have then adapted to the respective acidity of the habitat. Thus, the genetic properties of E. mutabilis could vary depending on the $\mathrm{pH}$ of the habitat. Therefore, we hypothesized that E. mutabilis strains isolated from different acidities of inland water habitats are genetically different. 
There are some reports on the phylogenetic analysis of E. mutabilis strains; however, the information is not sufficient to discuss the relationship between their biogeographic distribution and genetic diversity. The habitat conditions in acidic land water systems in Japan have already been reported [10,11]; however, phylogenetic information is still lacking. Our brief report documents the phylogenetic analysis of benthic Euglena populations isolated from acidic land water systems, under $\mathrm{pH}$ values ranging from 3.4 to 4.7 , in Southwestern Japan. These strains of the benthic Euglena sp. were identified as the Euglena mutabilis Schmitz, based on their morphological characteristics. The first objective of the present study was to identify the benthic Euglena strains by phylogenetic analysis of plastid SSU and nuclear SSU rRNA genes. We then discuss the genetic similarity of the strains with reference to the chemical parameters of the habitats.

\section{Materials and Methods}

\subsection{Study Sites}

We selected three study sites-habitats of the benthic Euglena sp. on Kyushu Island in Southwestern Japan. A strain of benthic Euglena sp. was isolated from coal mine drainage in Sensui, Kurate, Fukuoka (33.78264 ${ }^{\circ}$ N, $130.65363^{\circ}$ E, 16 m a.s.l.: Sensui drainage strain). The benthic Euglena sp. colonized and formed biofilms on the surface of the sediments and in streams flowing out of the abandoned coal mine. This population showed no visible accompanying species, and the Euglena cells aggregated and formed biofilms with a high population density. The biofilm was distributed from the mouth of the effluent (abandoned entrance to coal mining pit) to $c a .64 .1 \mathrm{~m}$ downstream from the mouth.

The other two strains of benthic Euglena sp. were isolated from biofilms on aquatic sediments in a volcanic area. One of them was isolated from a volcanic cold spring in the Bougatsuru mire, Oita, Northern Kyushu Island $\left(33.09602^{\circ} \mathrm{N}, 131.25940^{\circ} \mathrm{E}, 1238 \mathrm{~m}\right.$ a.s.l.: Bougatsuru spring strain). This Euglena population was established on the sediment at the orifice of the spring (out of ground water), with fibrous cyanobacterial mats. The other Euglena population was collected from a temporal pool in the Ebinokogen volcanic area of the Kirishima Volcanoes, Miyazaki, Southern Kyushu $\left(31.94864^{\circ} \mathrm{N}, 130.85560^{\circ} \mathrm{E}\right.$, $1243 \mathrm{~m}$ a.s.l.: Ebinokogen pool strain). The pool was surrounded by a flow of lava and stored a thousand liters of water at a temperature of $c a .16{ }^{\circ} \mathrm{C}$, which was likely to be affected by the present volcanic activity there. The vegetation in the pool includes Sphagnum cuspidatum Hoffm. and the pool community is categorized as the mire type. The collected population of benthic Euglena was established in the sediment of the pool along with fibrous cyanobacteria.

\subsection{Determination of Environmental Variables}

Field measurements ( $\mathrm{pH}$, electrical conductivity, and water temperature) and water collection were conducted at the orifice of the abandoned coal mine in Sensui (Sensui drainage) on 26 April 2019, at the spring out of the ground water in Bougatsuru (Bougatsuru spring) on 28 November 2019, and at the surface of the pool in Ebinokogen (Ebinokogen pool) on 17 May 2019.

In the Sensui drainage and the Bougatsuru spring, electrical conductivity (EC) and $\mathrm{pH}$ were measured in situ using EC (D-54, Horiba, Kyoto, Japan) and pH (D-52, Horiba, Kyoto, Japan) meters, respectively. The total organic carbon (TOC) concentration was determined in the laboratory for a non-filtered water sample, using a TOC analyzer (TOC-VCSH, Shimazu, Kyoto, Japan). Water samples were filtered using a $0.20 \mu \mathrm{m}$-pore-sized cellulose acetate membrane filter (Advantec Toyo), and major cations $\left(\mathrm{NH}_{4}{ }^{+}, \mathrm{Na}^{+}, \mathrm{K}^{+}, \mathrm{Mg}^{2+}\right.$, and $\left.\mathrm{Ca}^{2+}\right)$ and anions $\left(\mathrm{Cl}^{-}, \mathrm{NO}_{3}{ }^{-}, \mathrm{PO}_{4}{ }^{3-}\right.$, and $\left.\mathrm{SO}_{4}{ }^{2-}\right)$ were analyzed by ion chromatography (DX-120 and ICS-6000, Thermo Scientific Dionex, Thermo Fisher Scientific, Tokyo, Japan). Dissolved metals (Al, As, Fe, Mn, Pb, and Zn) were analyzed by ICP-AES/OES (ICPE-9800, Shimazu, Kyoto, Japan).

In the Ebinokogen pool, electrical conductivity (EC) and $\mathrm{pH}$ were measured in situ, using a portable water quality meter (LAQUA WQ-330, Horiba, Kyoto, Japan). Water 
samples were filtered with a $0.45 \mu \mathrm{m}$-pore-sized membrane filter (Advantec, Tokyo), and the major anions $\left(\mathrm{Cl}^{-}\right.$, and $\left.\mathrm{SO}_{4}{ }^{2-}\right)$ were analyzed by ion chromatography (DX-100, Thermo Scientific Dionex, Thermo Fisher Scientific, Tokyo, Japan). Major cations $\left(\mathrm{Na}^{+}, \mathrm{K}^{+}, \mathrm{Mg}^{2+}\right.$, and $\mathrm{Ca}^{2+}$ ) and dissolved metals (Al and Fe) were analyzed using ICP-AES (Model 5100, Agilent Technology, Tokyo).

\subsection{Collection and Isolation of the Euglena Population}

Sediment samples (containing benthic Euglena sp.) collected from the surface of sediments in the Sensui drainage on 26 April 2019, from the Bougatsuru spring on 28 November 2019, and the Ebinokogen pool on 17 May 2019, were used for isolation of the benthic Euglena sp. The samples contained both water and suspended sediment materials, from which the Euglena-containing biofilm community was carefully selected. Bottles with biofilms and sediments collected from mine drainage or volcanic springs were stirred lightly, and the sediment was allowed to precipitate. Euglena containing the biofilm community in the resulting supernatant was used for further culturing.

Purification of the Euglena population was carried out following a modified method of Zheng and Haraguchi [10]. After the removal of visible contaminants with a needle, the supernatant containing Euglena was cultured in a Hoagland solution without ammonium salts, and then transferred to an ammonium sulfate-enriched Hoagland solution (containing $1000 \mathrm{mg} \mathrm{L}^{-1}$ ammonium sulfate; $\left.\mathrm{pH}=3.07\right)$. Sodium chloride solution $(0.9 \%)$ was added to the culture solution (1:1) and centrifuged at $600 \mathrm{rpm}$ for $10 \mathrm{~min}$. After two centrifugations, a Euglena population without other microscopic visible species was obtained. This Euglena population was transferred to sterile plastic Petri dishes $(4.0 \mathrm{~cm}$ diameter, $1.0 \mathrm{~cm}$ depth) containing $20 \mathrm{~mL}$ of ammonium sulfate-enriched Hoagland solution. The population was cultured under illumination with a photosynthetic photon flux density (PPFD) of $185 \mu \mathrm{mol} \mathrm{s}^{-1} \mathrm{~m}^{-2}$ in a growth chamber $\left(25^{\circ} \mathrm{C}\right)$, by stirring at $65 \mathrm{rpm}$ for 7 days. Sodium chloride solution $(0.9 \%)$ was added to the culture solution $(1: 1)$ and centrifuged at $600 \mathrm{rpm}$ for $10 \mathrm{~min}$, and the precipitated Euglena population was inoculated on a plate of Cramer and Myers culture medium (CM medium), adjusted to a $\mathrm{pH}$ of 5.5 [12]. After 7 days of culturing on the solid Cramer and Myers medium at $25^{\circ} \mathrm{C}$, pure aggregates of Euglena (strains SEN, BOU, and KIRI) were obtained from the three study sites-the Sensui coal mine drainage, the Bougatsuru cold spring, and the Ebinokogen mire pool, respectively. The cultured Euglenoid strains were preliminarily identified based on their cells and chloroplast morphology, as well as ecological characteristics [2,7,11,13-15]. All benthic Euglenoid strains were tentatively identified as Euglena mutabilis Schmitz, by using an upright light microscope (Nikon ECLIPSE 80i, Tokyo, Japan) equipped with a digital camera (Nikon DS-Ri1, Tokyo, Japan) (Figure 1).

\subsection{Phylogenetic Analysis of SSU rRNA Genes}

Genomic DNA was extracted from approximately $0.1 \mathrm{~g}$ of the cell pellet of each $E$ uglena isolate using the DNeasy PowerSoil Kit (Qiagen), according to the manufacturer's instructions. The chloroplast SSU (16S) rRNA gene fragments were amplified by PCR using a forward primer (Bact27F: AGAGTTTGATCCTGGCTCAG) and reverse primer (Uni1490R: GGHTACCTTGTTACGACTT) [16]. The nuclear SSU (18S) rRNA gene fragments were amplified using primers 18S -F' (AWYTGGTTGATCCTGCCAG) and 18S R (GATCCTTCCGCAGGTTCACC) [17]. PCR amplification with KOD FX Neo (TOYOBO, Osaka, Japan) was performed using a Biometra TAdvanced 96 SG (Biometra, Göttingen, Germany). The PCR amplification conditions were as follows-initial denaturation at $98^{\circ} \mathrm{C}$ for $2 \mathrm{~min}$; 35 cycles of denaturation at $98^{\circ} \mathrm{C}$ for $10 \mathrm{~s}$, annealing at $50{ }^{\circ} \mathrm{C}$ for $45 \mathrm{~s}$, extension at $68{ }^{\circ} \mathrm{C}$ for $90 \mathrm{~s}$, and a final extension at $68^{\circ} \mathrm{C}$ for $7 \mathrm{~min}$. The PCR products were purified after gel electrophoresis, cloned into the pTA2 vector, and then transformed into chemically competent Escherichia coli DH5 $\alpha$ (TOYOBO, Osaka, Japan). Inserted DNA of positive colonies was PCR-amplified with M13-20 and M13 reverse primers, and sequenced using an ABI3730xl DNA analyzer [18]. The sequences obtained in this study were deposited in 
public databases under the following accession numbers: LC613032-LC613034 (plastid SSU rRNA gene) and LC613035-LC613037 (nuclear SSU rRNA gene). The obtained sequences were compared with similar sequences in the DDBJ/EMBL/GenBank non-redundant database, using the BLAST program, and were aligned with other known rRNA sequences using the MAFFT v.7.475. Taxonomic affiliation was determined based on a phylogenetic tree constructed using RAxML v8.2.12 with the GTR GAMMA model [19]. A bootstrap test of phylogeny was performed using 1000 replicates.

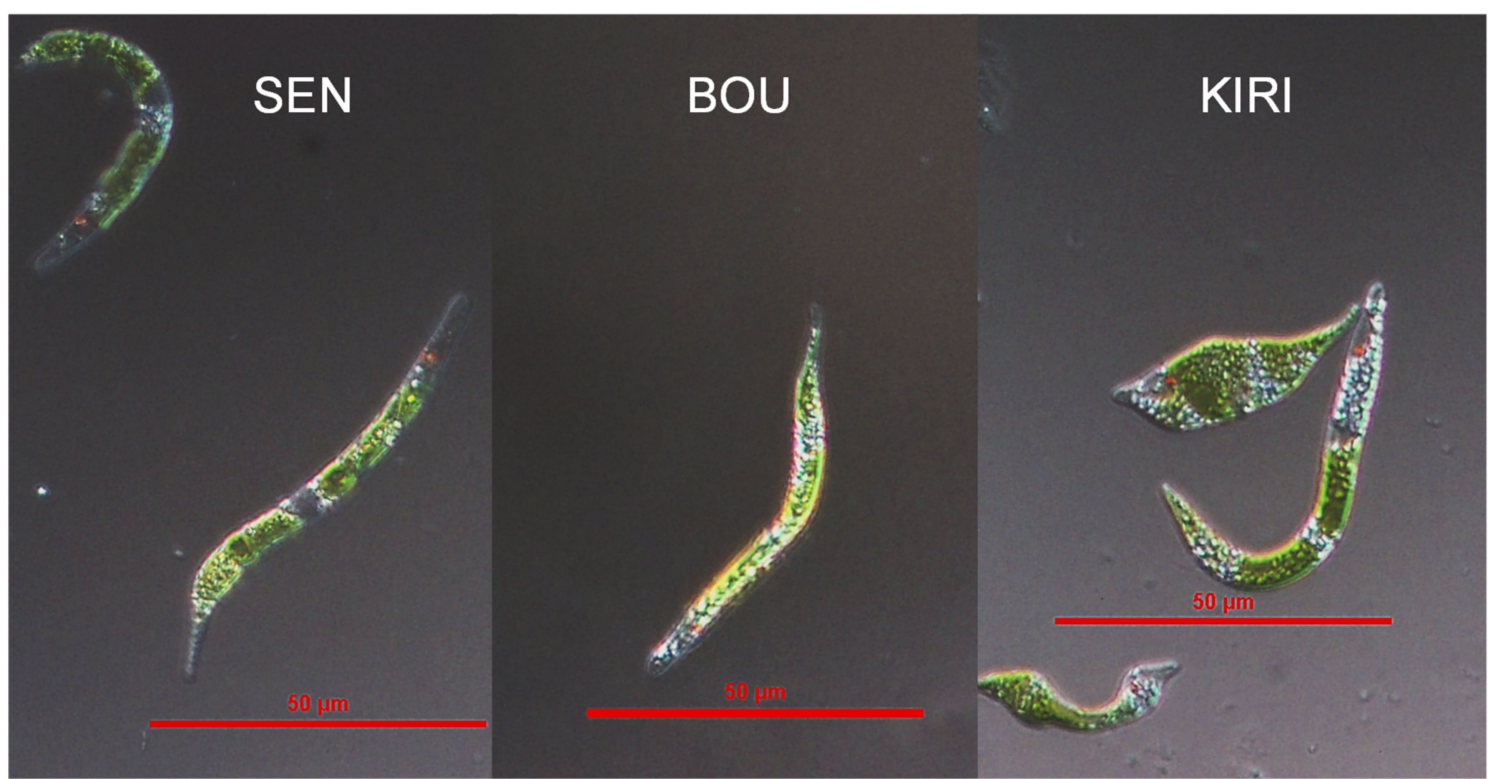

Figure 1. Upright light microscope micrographs of the Euglena mutabilis strains-SEN, BOU, and KIRI. Scale bars indicate $50 \mu \mathrm{m}$.

\section{Results and Discussion}

The length of the plastid SSU rRNA gene products of the three strains was 1401 base pairs. Phylogenetic analysis of these three strains showed high similarities amongst the plastid SSU rRNA gene sequences $(>99.86 \%$ ). The closest relative of the plastid SSU rRNA gene products was E. mutabilis CCAC0131 (accession number KX889696), with similarities of $99.71 \%, 99.86 \%$, and $99.86 \%$ for SEN, BOU, and KIRI, respectively (Table S1). The lengths of the nuclear SSU rRNA gene products of the SEN, BOU, and KIRI strains were 2452, 2456, and $2454 \mathrm{bp}$, respectively. Phylogenetic analysis of these three strains showed high similarities (greater than 99.76\%) for nuclear SSU rRNA gene sequences. One of the close relatives of the nuclear SSU rRNA gene product was E. mutabilis RT8n7 (accession number AY082988), with similarities of $98.86 \%, 98.94 \%$, and $98.94 \%$ for SEN, BOU, and KIRI, respectively (Table S2). Thus, the cultured strains were phylogenetically assigned as members of E. mutabilis.

The direct geographic distance between the two local populations of E. mutabilis ranged from 95 to $205 \mathrm{~km}$, and there was no continuum of aquatic systems among the sites. Nevertheless, we found very high similarity of both plastid SSU and nuclear SSU rRNA gene sequences among the three geographically isolated populations, in Southwestern Japan. The E. mutabilis strain CCAC0131 (isolated from Worringer Bruch, Cologne, Germany) is regarded as one of the closest relatives of the plastid SSU and nuclear SSU rRNA gene sequences of the three strains from Japan. Kim et al. [20] grouped the strain CCAC0131 together with strain ELC 1 (isolated from Lake Caviahue, Argentina; accession number EU090196 for nuclear SSU rRNA gene sequence) and strain RT8n7 (isolated from Rio Tinto, Spain; accession number AY082988 for nuclear SSU rRNA gene sequence), based on combined nuclear SSU, partial-LSU, plastid SSU, and partial-LSU rRNA gene sequences. Correspondingly, our phylogenetic analysis suggested that the cultured Japanese strains, 
SEN, BOU, and KIRI formed a distinct clade with CCAC0131 from Germany and ELC1 from Argentina. This phylogenetic group, including CCAC0131, ELC1, and the three Japanese strains shared $>98 \%$ gene similarity with each other, in the plastid SSU and nuclear SSU rRNA gene trees.

The EC and pH of the habitats of E. mutabilis in Sensui, Bougatsuru, and Ebinokogen ranged from 24 to $185 \mathrm{mS} / \mathrm{m}$ and 3.4-4.7 (Table 1). The $\mathrm{pH}$ of the Sensui drainage ranged from 3.61-4.10 during 3 October 2007 to 26 April $2019(\mathrm{n}=12)$, and the $\mathrm{pH}$ of the Bougatsuru spring ranged 4.61-5.30 during 13 July 2006 to 28 November 2018 ( $\mathrm{n}=19$; AH unpublished data), implying low fluctuation of $\mathrm{pH}$ in these two habitats ( $<0.7 \mathrm{pH}$ unit). Although the water of the three habitats was acidic, a larger $\mathrm{EC}$ range implies a variable ionic strength among the three habitats. Among chemical variables, $\mathrm{SO}^{2-}{ }^{2-} \mathrm{Ca}^{2+}, \mathrm{Al}$, and Fe showed 7-70 fold of differences among the three studied habitats. Mine drainage water in Sensui was characterized by high sulfuric acid contamination and consequently, a greater number of leached elements (e.g., calcium, aluminum, iron, manganese, lead, and zinc) from mineral materials in the mining pit. Water in the volcanic area was affected by sulfuric acid; however, the concentration of sulfate was lower than that in the Sensui mine drainage water. The acidity of the water in the Ebinokogen pool was the highest among the three habitats, and was characterized by high concentrations of aluminum and iron. Sulfidic springs in Bougatsuru showed high sulfide concentrations of up to $1.8 \mathrm{mg} / \mathrm{L}$.

Table 1. Quality of stream water at the habitats of Euglena mutabilis in Sensui, Bougatsuru, and Ebinokogen. * analyzed by AH.

\begin{tabular}{|c|c|c|c|c|}
\hline Location & & $\begin{array}{c}\text { Sensui } \\
\text { coal mine drainage } \\
33.78264^{\circ} \mathrm{N} \\
130.65363^{\circ} \mathrm{E} \\
16 \mathrm{~m} \text { a.s.l. } \\
\text { (26 April 2019) }\end{array}$ & $\begin{array}{c}\text { Bougatsuru } \\
\text { cold spring } \\
33.09602^{\circ} \mathrm{N} \\
131.25940^{\circ} \mathrm{E} \\
1238 \mathrm{~m} \text { a.s.l. } \\
\text { (28 November } 2019)\end{array}$ & $\begin{array}{c}\text { Ebinokogen } \\
\text { mire pool } \\
31.94864 \\
130.85560 \\
1243 \text { m a.s.l. } \\
\text { (17 May 2019) }\end{array}$ \\
\hline Water temperature & ${ }^{\circ} \mathrm{C}$ & 22.5 & 10.2 & 16.2 \\
\hline $\mathrm{pH}$ & & 4.10 & 4.78 & 3.41 \\
\hline $\mathrm{EC}$ & $\mathrm{mS} / \mathrm{m}$ & 185 & 24.5 & 81.7 \\
\hline $\mathrm{Cl}^{-}$ & $\mathrm{mg} / \mathrm{L}$ & 38.1 & 14.3 & 57.0 \\
\hline $\mathrm{NO}_{3}^{-}$ & $\mathrm{mg} / \mathrm{L}$ & 1.2 & 1.2 & not determined \\
\hline $\mathrm{PO}_{4}^{3-}$ & $\mathrm{mg} / \mathrm{L}$ & 0.0 & 0.0 & 0.0 \\
\hline $\mathrm{SO}_{4}^{2-}$ & $\mathrm{mg} / \mathrm{L}$ & 1375.0 & 170.1 & 210.0 \\
\hline $\mathrm{Na}^{+}$ & $\mathrm{mg} / \mathrm{L}$ & 31.2 & 11.8 & 24.1 \\
\hline $\mathrm{NH}_{4}^{+}$ & $\mathrm{mg} / \mathrm{L}$ & 2.9 & 1.8 & 0.0 \\
\hline $\mathrm{K}^{+}$ & $\mathrm{mg} / \mathrm{L}$ & 3.0 & 1.5 & 5.4 \\
\hline $\mathrm{Mg}^{2+}$ & $\mathrm{mg} / \mathrm{L}$ & 11.3 & 6.8 & 12.3 \\
\hline $\mathrm{Ca}^{2+}$ & $\mathrm{mg} / \mathrm{L}$ & 131.3 & 19.5 & 32.8 \\
\hline $\mathrm{Al}$ & $\mathrm{mg} / \mathrm{L}$ & 20.9 & 0.3 & 9.86 \\
\hline As & $\mathrm{mg} / \mathrm{L}$ & 0.2 & 0.1 & $1.5^{*}$ \\
\hline $\mathrm{Fe}$ & $\mathrm{mg} / \mathrm{L}$ & 56.2 & 2.8 & 25.9 \\
\hline
\end{tabular}

The water quality of the three habitats of E. mutabilis in this study was different; however, the genetic similarity among these three strains was extremely high. This suggests that these three strains originated from a common ancestral lineage and diverted to these different habitats. Furthermore, plastid SSU and nuclear SSU rRNA gene sequences of these three strains were highly similar to the E. mutabilis strains distributed globally. The $\mathrm{pH}$ values of Lake Caviahue (strain ELC1) and Rio Tinto (strain RT8n7) were lesser than 3.0, and 2.0, respectively [21,22], whereas the $\mathrm{pH}$ of surface soil of Worringer Bruch (strain CCAC0131) was 5.9 [23]. Although the pH data in Worringer Bruch was of surface soil, the value shows less effect of sulfuric acid contamination after oxidation of pyrite. $E$. mutabilis strain PM1 (JF694007) shared a high level of similarity with the nuclear SSU rRNA genes of the three strains and was isolated from an abandoned copper mine drainage $(\mathrm{pH}$ 
2.5) in Parys, Wales [24]. Furthermore, environmental clone B89 (KX501172), with which the plastid SSU rRNA genes of the cultured strains in this study shared a high level of similarities, was PCR-amplified from an acid mine drainage sediment ( $\mathrm{pH}$ 2.77-2.96) at Scalp Level Run, Cambria County, Pennsylvania, USA [25]. The lower red eye (LRE) clones in Figure 1 were obtained from acidic coal mine drainage ( $\mathrm{pH}$ 2.5-4.5) in Somerset County, Pennsylvania, USA [26]. The $\mathrm{pH}$ of the habitats of the three Japanese strains was higher $(\mathrm{pH}=3.4-4.7)$ than that of the Euglena habitats described above. Taken together, the $\mathrm{pH}$ conditions in close relation with the phylogenetic group represented in Figure 2, ranged from 2.0 to 5.9. This implies that the genetic diversity of E. mutabilis was very low, even within the populations colonizing a wide $\mathrm{pH}$ range. Thus, our hypothesis that ' $E$. mutabilis strains isolated from inland water habitats of different acidities are genetically different,' was rejected. The physiological mechanism of $\mathrm{pH}$ regulation in E. mutabilis should be clarified in future research.
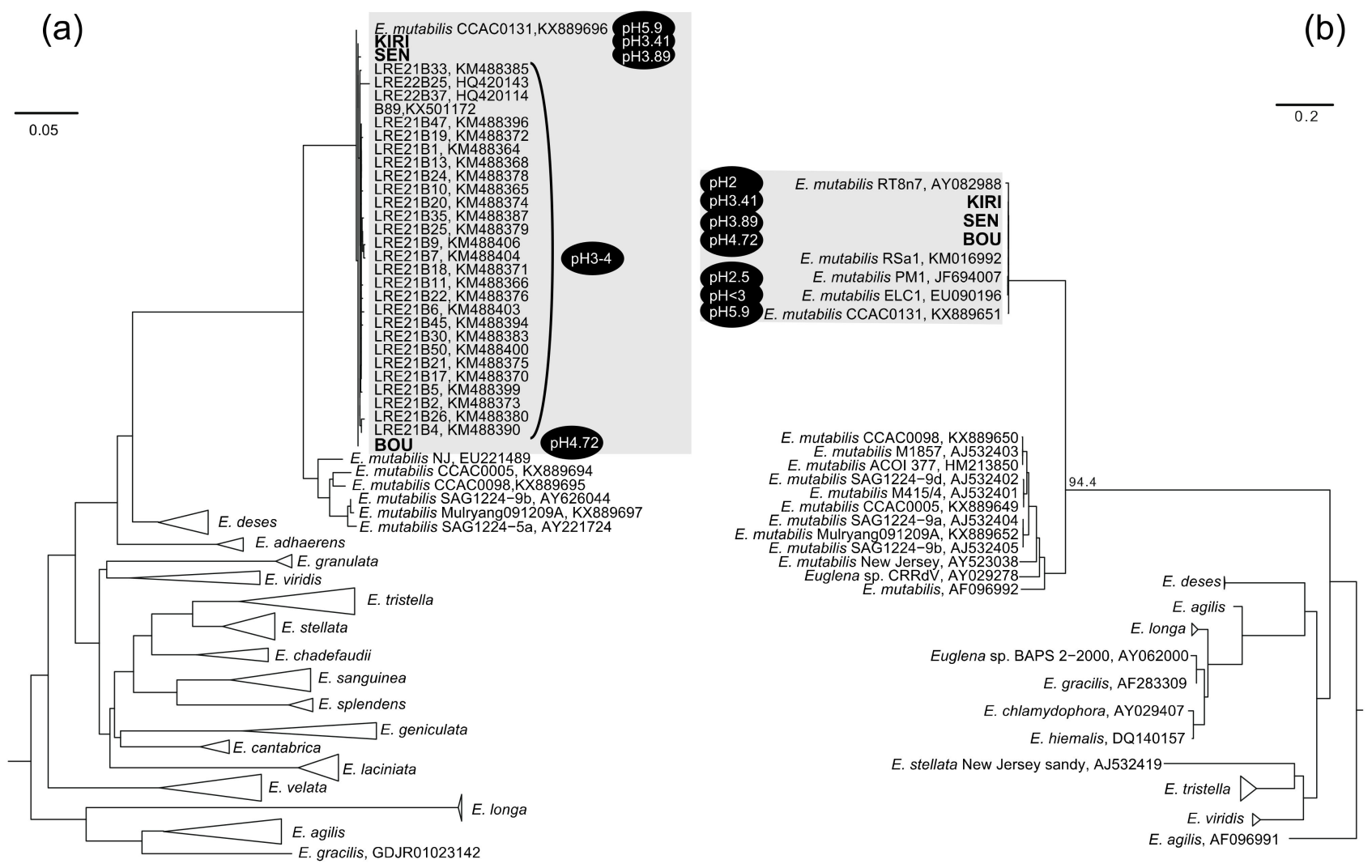

Figure 2. Phylogenetic tree of plastid SSU rRNA genes (a) and nuclear SSU rRNA genes (b) to show the phylogenetic position of the strains SEN, BOU, and KIRI in the context of the Euglenoids group. The sequences in bold were obtained in this study. Bootstrap values are expressed as percentages of 1000 trials. The values at the nodes represent scores greater than 50\%. The Euglena mutabilis group with a high similarity (greater than $98 \%$ ) are shaded, in which all available sequences from NCBI database were included.

\section{Conclusions}

Phylogenetic analysis among three strains of E. mutabilis isolated from sediments in acidic inland water systems $(\mathrm{pH}=3.4-4.7)$ in Southwestern Japan showed high similarities to plastid SSU and nuclear SSU rRNA gene sequences. They were closely related to the cultured isolates from other highly acidic habitats $(\mathrm{pH}=2.0-5.9)$. Concentration of $\mathrm{SO}_{4}{ }^{2-}$ had extremely wide range of values that ranged from $170-1375 \mathrm{mg} / \mathrm{L}$, among the studied three habitats in Japan. Aluminum, calcium, and iron also had 7-70 fold of differences among the three habitats. Our results imply that the rRNA genes of E. mutabilis have 
compensated for their low genetic diversity by adapting to a wide $\mathrm{pH}$ range, as well as various water chemistries of habitats.

Supplementary Materials: The following are available online at https:/ / www.mdpi.com/article / 10.3390/w13111570/s1, Table S1: Different nucleotides in plastid SSU rRNA gene sequence from strains of Euglena mutabilis. Table S2: Different nucleotides in nuclear SSU rRNA gene sequence from strains of Euglena mutabilis. Number of position of sequence includes missing nucleotides.

Author Contributions: Conceptualization, A.H. and K.Y. (Katsunori Yanagawa); methodology, A.H. and K.Y. (Katsunori Yanagawa); validation, A.H.; formal analysis, A.H., K.Y. (Kai Yoshitake), K.A., M.H., and K.Y. (Kei Yamashita); investigation, K.Y. (Katsunori Yanagawa), A.H., K.Y. (Kai Yoshitake), K.A., M.H., and K.Y. (Kei Yamashita); writing-original draft preparation, A.H. and K.Y. (Katsunori Yanagawa); writing—review and editing, A.H., K.Y. (Kai Yoshitake), and J.-i.I.; funding acquisition, K.Y. (Kei Yamashita). All authors have read and agreed to the published version of the manuscript.

Funding: This work was supported in part by the Japan Society for the Promotion of Science (JSPS) KAKENHI Grant Number 20K05404.

Institutional Review Board Statement: Not applicable.

Informed Consent Statement: Not applicable.

Data Availability Statement: Not applicable.

Acknowledgments: We thank Takeshi Matsushima, Syogo Oshima, and Harue Masuda for their support in the sample collection. During our sampling at Ebinokogen, we obtained permission to enter a restricted area from Ebino city.

Conflicts of Interest: The authors declare no conflict of interest.

\section{References}

1. Rijstenbil, J.W.; Merks, A.G.A.; Peene, J.; Poortvliet, T.C.W.; Wijnholds, J.A. Phytoplankton composition and spatial distribution of copper and zinc in the Fal Estuary (Cornwall, UK). Hydrobiol. Bull. 1991, 25, 37-43. [CrossRef]

2. Brake, S.S.; Dannelly, H.K.; Connors, K.A.; Hasiotis, S.T. Influence of water chemistry on the distribution of an acidophilic protozoan in an acid mine drainage system at the abandoned Green Valley coal mine, Indiana, USA. Appl. Geochem. 2001, 16, 1641-1652. [CrossRef]

3. Gross, W.; Oesterhelt, C.; Tischendorf, G.; Lederer, F. Characterization of a non-thermophilic strain of the red algal genus Galdieria isolated from Soos (Czech Republic). Eur. J. Phycol. 2002, 37, 477-482. [CrossRef]

4. Pentecost, A. The distribution of Euglena mutabilis in Sphagna, with reference to the Malham Tarn Noethern Fen. Field Stud. 1982, 5, 591-606.

5. Searles, P.S.; Kropp, B.R.; Flint, S.D.; Caldwell, M.M. Influence of solar UV-B radiation on peatland microbial communities of southern Argentinia. New Phytol. 2001, 152, 213-221. [CrossRef]

6. Casiot, C.; Bruneel, O.; Personné, J.C.; Leblanc, M.; Elbaz-Poulichet, F. Arsenic oxidation and bioaccumulation by the acidophilic protozoan, Euglena mutabilis, in acid mine drainage (Carnoulès, France). Sci. Total Environ. 2004, 3202, 259-267. [CrossRef] [PubMed]

7. Hargreaves, J.W.; Lloyd, E.J.H.; Whitton, B.A. Chemistry and vegetation of highly acidic streams. Freshw. Biol. 1975, 5, 563-576. [CrossRef]

8. Sabater, S.; Buchaca, T.; Cambra, J.; Catalan, J.; Guasch, H.; Ivorra, N.; Muñoz, I.; Navarro, E.; Real, M.; Romaní, A. Structure and function of benthic algal communities in an extremely acid river. J. Phycol. 2003, 39, 481-489. [CrossRef]

9. Bray, J.P.; Broady, P.A.; Niyogi, D.K.; Harding, J.S. Periphyton communities in New Zealand streams impacted by acid mine drainage. Mar. Freshw. Res. 2008, 59, 1084-1091. [CrossRef]

10. Zheng, J.; Haraguchi, A. Inorganic nitrogen source for autotrophic growth of Euglena mutabilis Schmitz. Phycol. Res. 2018, 66, 155-158. [CrossRef]

11. Negoro, K. On a Euglena sp. from acidic mineral water in Japan. J. Plant Res. (Bot. Mag. Tokyo) 1943, 57, 132-136, (in Japanese with German summary).

12. Cramer, M.; Myers, J.C. Growth and photosynthetic characteristics of Euglena gracilis. Arch. Microbiol. 1952, 17, 384-402. [CrossRef]

13. Hädder, D.P.; Melkonian, M. Phototaxis in the gliding flagellate, Euglena mutabilis. Arch. Microbiol. 1983, 135, 25-29. [CrossRef]

14. Surek, B.; Melkonian, M. A cryptic cytostome is present in Euglena. Protoplasma 1986, 133, 39-49. [CrossRef]

15. Wołowski, K.; Turnau, K.; Henriques, F.S. The algal flora of an extremely acidic, metal-rich drainage pond of São Domingos pyrite mine (Portugal). Cryptogam. Algol. 2008, 29, 313-324.

16. DeLong, E.F. Archaea in coastal marine environments. Proc. Natl. Acad. Sci. USA 1992, 89, 5685-5689. [CrossRef] 
17. Sittenfeld, A.; Mora, M.; Ortega, J.M.; Albertazzi, F.; Cordero, A.; Roncel, M.; Sánchez, E.; Vargas, M.; Fernández, M.; Weckesser, J.; et al. Characterization of a photosynthetic Euglena strain isolated from an acidic hot mud pool of a volcanic area of Costa Rica. FEMS Microbiol. Ecol. 2002, 42, 151-161. [CrossRef]

18. Yanagawa, K.; Shiraishi, F.; Tanigawa, Y.; Maeda, T.; Mustapha, N.A.; Owari, S.; Tomaru, H.; Matsumoto, R.; Kano, A. Endolithic microbial habitats hosted in carbonate nodules currently forming within sediment at a high methane flux site in the Sea of Japan. Geosciences 2019, 9, 463. [CrossRef]

19. Stamatakis, A. RAxML Version 8: A tool for Phylogenetic Analysis and Post-Analysis of Large Phylogenies. Bioinformatics 2014, 30, 1312-1313. [CrossRef]

20. Kim, J.I.; Linton, E.W.; Shin, W. Morphological and genetic diversity of Euglena deses group (Euglenophyceae) with emphasis on cryptic species. Algae 2016, 31, 219-230. [CrossRef]

21. Beamud, S.G.; Diaz, M.M.; Pedrozo, F.L. Nutrient limitation of phytoplankton in a naturally acidic lake (Lake Caviahue, Argentina). Limnology 2010, 11, 103-113. [CrossRef]

22. Zettler, L.A.A.; Gómez, F.; Zettler, E.; Keenan, B.G.; Amils, R.; Sogin, M.L. Eukaryotic diversity in Spain's River of Fire. Nature 2002, 417, 137. [CrossRef] [PubMed]

23. Kloos, K.; Hüsgen, U.M.; Bothe, H. DNA-probing for genus coding for denitrification, $\mathrm{N}_{2}$-fixation and nitrification in bacteria isolated from different soils. Z. Nat. 1998, 53c, 69-81.

24. Ňancucheo, I.; Johnson, D.B. Acidophilic algae isolated from mine-impacted environments and their roles in sustaining heterotrophic acidophiles. Front. Microbiol. 2012, 3, 325. [CrossRef] [PubMed]

25. Grettenberger, C.L.; Pearce, A.R.; Bibby, K.J.; Jones, D.S.; Burgos, W.D.; Macalady, J.L. Efficient low-pH iron removal by a microbial iron oxide mound ecosystem at Scalp Level Run. Appl. Environ. Microbiol. 2017, 83, e00015-17. [CrossRef] [PubMed]

26. Jones, D.S.; Kohl, C.; Grettenberger, C.; Larson, L.N.; Burgos, W.D.; Macalady, J.L. Geochemical niches of iron-oxidizing acidophiles in acidic coal mine drainage. Appl. Environ. Microbiol. 2015, 81, 1242-1250. [CrossRef] [PubMed] 